\title{
TRAJECTORY ANALYSIS OF FOREST CHANGES IN NORTHERN AREA OF CHANGBAI MOUNTAINS, CHINA FROM LANDSAT TM IMAGE
}

\author{
F.Huang $^{\mathrm{a},}$ *, H.J.Zhang ${ }^{\mathrm{b}}$, P.Wang ${ }^{\mathrm{a}}$ \\ ${ }^{\text {a }}$ School of Urban and Environmental Sciences, Northeast Normal University, 130024 Changchun, China - \\ joycehf@126.com \\ ${ }^{\mathrm{b}}$ School of Computer Science and Information Technology, Northeast Normal University, Changchun 130117, China - \\ lovercrane@hotmail.com
}

Commission VIII, WG VIII/8

KEY WORDS: Land cover, trajectory analysis, Forest, Landsat, GIS, Changbai Mountains,

\begin{abstract}
:
Based on the information from integrated Landsat TM/ETM images and geographic information systems (GIS), using dynamic model, landscape indices and temporal trajectory analysis, spatio-temporal changes in forest in the northern area of Changbai Mountains were investigated in the past 20 years. The results showed that the forests decreased by 141461 ha at the annual decrease rate of $0.19 \%$ from 1986 to 2006 . The numbers of forest patch increased, while the patch size of forest land declined. Forestland experienced the process of substantial fragmentation. Close forest showed a net reduction of $13.3 \times 10^{4}$ ha. The typical trajectories of forest changes included forestland-forestland-cropland, forestland-cropland-cropland, forestland-forestland-grassland and forestlandcropland-built-up land. The total area of human-induced change is 1.7 times than that of natural change in the study area. Population, cropland area and gross domestic product increased significantly as forests decreased.
\end{abstract}

\section{INTRODUCTION}

Forest plays a critical role in the global terrestrial ecosystems. With the economic development and population growth, forest ecosystems are being rapidly degraded or endangered in many regions of the world ( $\mathrm{Li}$ et al. 2009). Forest fragmentation due to land use is a major reason for the declining biodiversity in forest ecosystems and considered to be a primary threat to terrestrial biodiversity (Harris 1984; Armsworth et al. 2004; Pichancourt et al. 2006; Cakir et al. 2008). Quantitative and spatial forest change information is critical for addressing many pressing issues including global climate change, carbon budgets and sustainability.

Changbai Mountain, the highest mountain in the east of the Eurasian Continent, is covered with a wide range of distinct altitudinal vegetation types featuring the Earth's richest biodiversity in the cool temperate zone (Tang et al. 2011). Coupling with natural disturbance (e.g. fire, insects), substantial losses of the old-growth forests and fragmentation in forest landscapes of Northeast China has been found during the last decades, driven from human activities, especially forest clearcutting, logging and agricultural encroachment. Most of the mixed broadleaf/Korean pine (Pinus koraiensis) forests have been replaced (plantation-style) by faster-growing species such as larch (Larix sp.), poplar (Populus sp.) and birch (Betula sp.) (Jiang et al. 1999; Xiao et al. 2002). Till now, most of the efforts have been focused on the forest landscape change in Changbai Mountain Nature Reserve and its surrounding areas or in the forested areas under the jurisdiction of forestry enterprises (Zheng et al. 1997; Zhao et al. 2001; Chang et al. 2003, 2004; Yu et al. 2004; Hao et al. 2004; Liu et al. 2005a; Wang et al. 2009; Deng et al. 2010; Huang and Jiang 2010; Tang et al. 2010; Dai et al. 2010). The objectives of this study were to quantify the spatio-temporal pattern of forests, and to characterize the forests fragmentation process and forest change trajectories of Yanbian Korean Autonomous Prefecture in the northern foot of the Changbai Mountains during 1986-2006.

\section{STUDY AREA}

The study area is located in $41^{\circ} 59^{\prime}-44^{\circ} 30^{\prime} \mathrm{N}, 127^{\circ} 27^{\prime}-131^{\circ} 18^{\prime} \mathrm{E}$, which covers an area of $4.3 \times 10^{4} \mathrm{~km}^{2}$, accounting for a quarter of the total area of Jilin Province. It borders Russia in the east and faces Democratic People's Republic of Korea across the Tumen River in the south. Bearing a temperate humid monsoon climate, the study area is characterized by four clear seasons. Annual mean temperature in this area is between 2 and $6^{\circ} \mathrm{C}$, and annual average precipitation ranges from 400 to $650 \mathrm{~mm}$. The sunshine duration is $2300-2800$ hours, and no ground frost exists for 50 100 days. The annual average wind velocity is $2-4 \mathrm{~m} / \mathrm{s}$. Here the broadleaved/Korean pine (Pinus koraiensis) forest dominates. The main soil types include grey-brown forest soil, white starched soil and meadow soil. Since the 1950s, largescale clear cutting and selective cutting have been made in this area, which resulted in gradual degradation of the forest ecosystem (Zhang et al. 1999). Historically, the prefecture consisted mainly of remote agricultural communities engaged in small scale farming, especially rice farming. Agriculture has been a very important pillar of the local economy throughout the study area for a long period.

\section{METHODS}

\footnotetext{
* Corresponding author.
} 


\subsection{Data source}

Landsat TM and ETM satellite images from China Remote Sensing Satellite Ground Station (RSGS), Chinese Academy of Sciences (CAS) were acquired. These digital images covering the entire studied area included 18 cloud-free or low cloudy cover scenes of images from June to September in the years of 1986, 2000 and 2006 respectively. Land use types are easy to identify in this period when plant grows abundantly in Northeast China.

Land cover types for the Yanbian prefecture were summarized as follows: (1) cropland, (2) forestland, (3) grassland, (4) water area, (5) built-up land and (6) unused land. Forestland is classified as closed forest, shrub, open forest, and other forest. Closed forest is natural or man-made forest with canopy cover of more than $30 \%$.Shrub is land covered by tree less than 2 meters high and with the canopy cover greater than $40 \%$. Open forest refers to land covered by trees with canopy cover between $10 \%$ and $30 \%$.Other forest is land covered by orchid and/or non- grownup forest.

Landsat images were georectified to 1:100 000 topographic maps using ground control points (GCPs) collected by global positioning system (GPS). The images acquired in 1986 were used as reference to correct the other scenes in 2000 and 2006.The maximum likelihood classifier was utilized to carry out classification of images. To revise the misclassification errors such as boundary and spectral confusion in preliminary classification, visual interpretation and ground survey were performed (Liu et al. 2005b). Reference data for 1986 Landsat images were acquired from the topographic maps (scale 1:100000) drawn in the same periods. The accuracy of classification for land cover maps extracted from Landsat images was assessed in 2001 and 2008 based on a reference data of randomly selected patches. The accuracy assessment was based on an evaluation of 400 patches. The overall accuracies of the four land cover maps interpreted from remote sensing images for 1986, 2000 and 2006 were 91\%, 92\% and $91 \%$, respectively.

\subsection{Dynamic Degree Model}

The dynamic degree model was applied to reveal the change rate of forest during different periods (Wang and Bao 1999). The calculation is given by

$$
K=\frac{U_{b}-U_{a}}{U_{a}} \times \frac{1}{T} \times 100 \%
$$

where $K$ is the dynamic degree of forest measured as the relative annual change rate, $U_{a}$ and $U_{b}$ are the area of forest in the start and final year, respectively, and $T$ is the interval of the calculating period (in years). A positive dynamic degree value generally indicates an increasing trend of forest coverage for a specific period, vice versa.

\subsection{Fragmentation Analysis}

The spatial composition and configuration of forest landscape pattern were described with following landscape indices, namely the number of patches (NP), mean patch size (MPS), patch density (PD) and area-weighted mean patch fractal dimension (AWMPFD). NP is a simple index of the degree of subdivision of a land cover type (McGarigal and Marks 1995), and MPS is a commonly used metric revealing the fragmentation in the spatial pattern analysis (Baldi et al. 2006). $\mathrm{PD}$ describes the density of patches for each land use, representing an aspect of fragmentation, which is the dissection of patches. AWMPFD reflects shape complexity weighted by the area of patches (Wang et al.2009, Huang et al.2012).

\subsection{Temporal Trajectory Establishment}

The temporal trajectory method is not only on what has changed between dates, but also on the progress of the change over the period (Mertens and Lambin 2000; Petit et al. 2001; Liu and Zhou, 2004; Zhou et al. 2004; Zhou et al.2008). In this study, the classified land cover maps were integrated using raster format within ArcGIS, thereafter the pixel-based change trajectories were constructed. The result is a temporal trajectory map, in which every pixel has a code corresponding to its trajectory. The possible change trajectories from 1986 to 2006 in the study area are shown in Figure.1. For example, the highlighted trajectory is specified as F-F-C, meaning that the land was found to be forestland in 1986, forest in 2000 and cultivated as cropland in 2006.

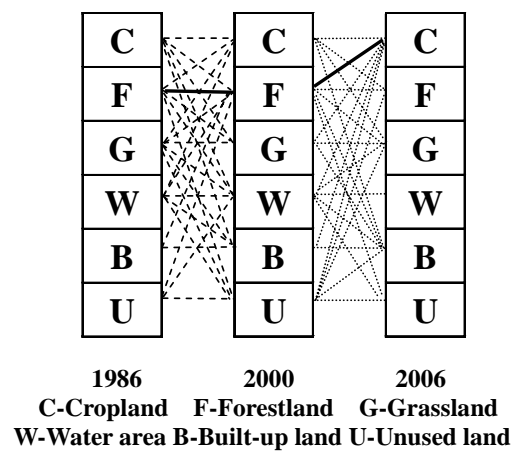

Figure 1. All possible trajectories of land use change

\section{RESULTS AND DISCUSSION}

\subsection{Area Change and Change Rate of Forest}

The temporal changes in forestland during 1986-2006 were shown in Table 1 . The process of spatial change of the forest land in the studied area was shown in Figure. 2. It was found that area of forest shrank continuously in the past two decades. In 1986, the forest covered about $82.2 \%$ of the total land area. Owing to the degradation of closed forest and open forest, forest area decreased significantly during 1986-2006.The net loss of forestland was $1414.61 \mathrm{~km}^{2}$. Closed forest decreased by $1249.20 \mathrm{~km}^{2}$ during 2000-2006, accounting for 92.1 per cent of the total reduced forest area in this period. In this period, loss of open forest and shrub were more remarkable than that from 1986 to 2000.In 2006, forest declined to $78.9 \%$ of the total area. The quality of forest has severely worsened in the past 20 years, and considerable decrease in forest was mainly attributed to reduction of closed forest. 


\begin{tabular}{|c|c|c|c|c|c|}
\hline Period & Change & $\begin{array}{c}\text { Closed } \\
\text { forest }\end{array}$ & Shrub & $\begin{array}{l}\text { Open } \\
\text { forest }\end{array}$ & $\begin{array}{l}\text { Other } \\
\text { forest }\end{array}$ \\
\hline \multirow{2}{*}{$\begin{array}{c}1986 \\
-2000\end{array}$} & area & -83.16 & -3.85 & -20.45 & 49.91 \\
\hline & rate(\%) & 0 & 0 & -0.10 & 0.90 \\
\hline \multirow{2}{*}{$\begin{array}{c}2000 \\
-2006\end{array}$} & area & -1249.2 & $\begin{array}{c}- \\
47.52\end{array}$ & -60.68 & 0.34 \\
\hline & rate(\%) & -0.50 & -0.70 & -0.70 & 0 \\
\hline \multirow{2}{*}{$\begin{array}{c}1986 \\
-2006\end{array}$} & change & -1332.36 & $\begin{array}{c}- \\
51.38\end{array}$ & -81.13 & 50.25 \\
\hline & rate(\%) & -0.19 & -0.25 & -0.29 & 0.64 \\
\hline
\end{tabular}

Table 1. The area changes of different forest types $\left(\mathrm{km}^{2}\right)$
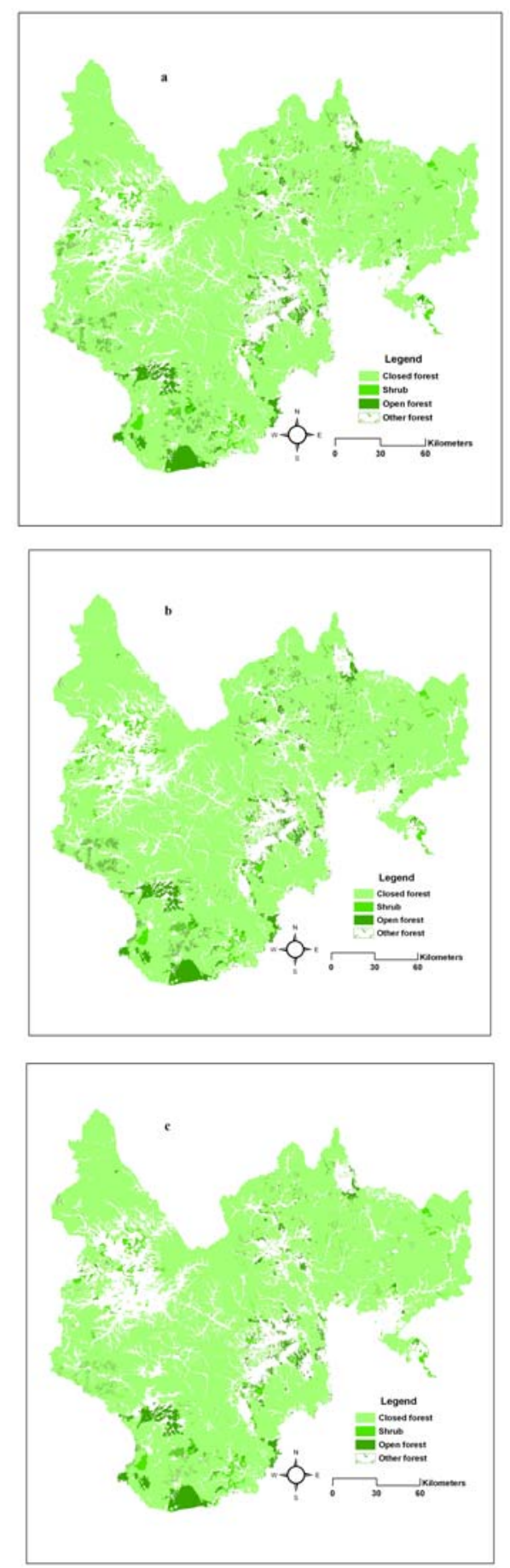

Figure 2. Forest in study area in 1986(a), 2000(b), 2006(c)
In summary, forest has decreased at an annual change rate of 0.19\% during 1986-2000. Closed forest was destroyed with annual loss rate of $-0.5 \%$ from 2000 to 2006 . The open forest decreased dramatically with annual rate of $-0.7 \%$ in the same period. Shrub forest shrunk in area between 1986 and 2000 at loss rate of $-0.25 \%$. There was an increase of other forest land with annual area change rate of $0.90 \%$ (from 1986 to 2000) and $0.64 \%$ (from 2000 to 2006) respectively. The speed of deforestation from 2000 to 2006 was faster. The change rates of various forests were relatively high showing a negative state.

\subsection{Forest Fragmentation}

Figure 3 shows the landscape metrics for forests at class level in different historical years. During the past 20 years, the numbers of forest patch increased slightly, while the average patch area decreased 96 ha. Forest decreased in the average size of patches potentially resulting from cultivation and degradation. From 1986 to 2006, the PD of forests increased from 0.059 per 100 ha to 0.062 per 100 ha. Forest land in this region affected by human activities have lower AMWPFD values $(<1.30)$. AWMPFD of forests decreased slightly indicating that forest patch shape tended to be regular and simpler indicating more human influence during 1986-2006. The averages patch area of closed forest decreased 2737ha resulting from logging and cultivation. The MPS values of shrubs and open forest decreased while averages patch area of other forest increased probably due to the afforestation encouraged by the government. The AWMPFD of closed forest and shrub decreased by 0.002 and 0.003 , respectively. It was concluded that forestland experienced the process of substantial clearing and fragmentation in the past 20 years.
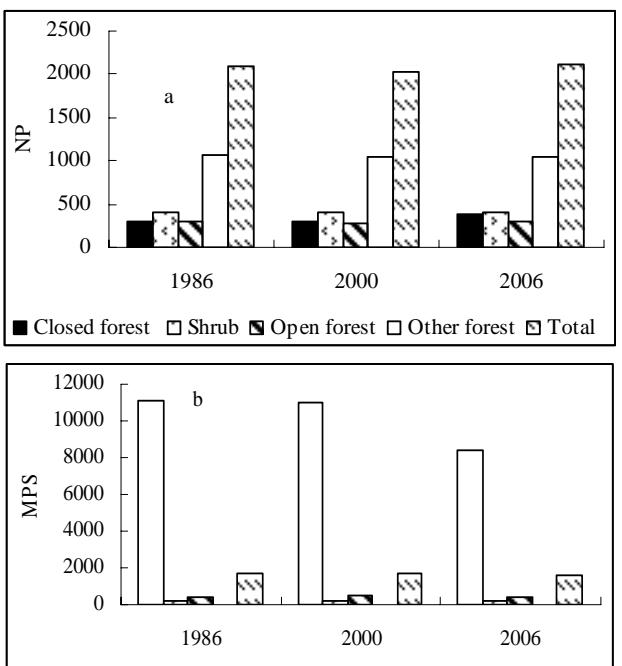

$\square$ Closed forest $\square$ Shrub $\square$ Open forest $\square$ Other forest $\square$ Total

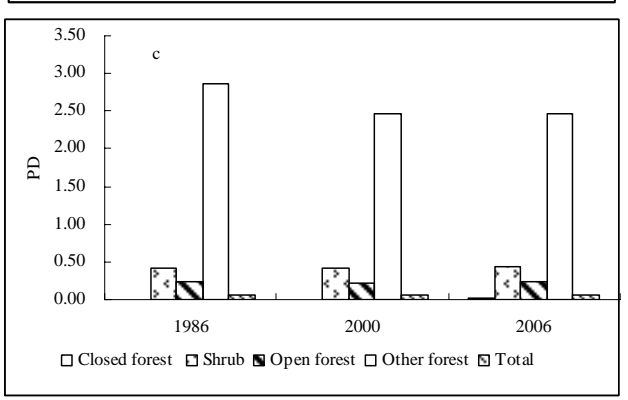




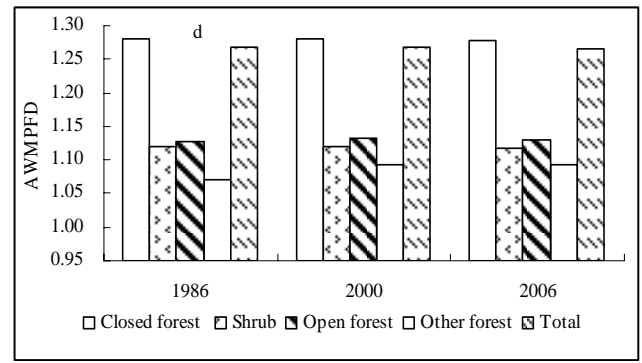

Figure 3. Landscape metrics of forest

\subsection{Forest Change Trajectory}

All found trajectories were classified into three classes, namely, unchanged, human-induced change and natural changes (Table 2). The unchanged class indicates that forest cover was found on the same analyzed pixel over the past 20 years. The humaninduced change class includes decisive changes due to human activities such as cultivation, logging, reforestation and construction. The representative trajectories of this class include F-C-C, F-F-C, F-F-B and C-C-F. The conversion between forest and other natural cover types are defined as natural changed trajectories in the study area during 1986-2006. Examples of trajectories of this class are F-F-G, F-G-G, G-G-F and G-F-F.

\begin{tabular}{|c|c|c|c|}
\hline Level 1 classes & Level 2 classes & $\begin{array}{c}\text { Trajectorie } \\
\text { s }\end{array}$ & $\begin{array}{c}\text { Area } \\
\text { (ha) }\end{array}$ \\
\hline \multirow{11}{*}{$\begin{array}{c}\text { Unchanged } \\
\text { Natural change }\end{array}$} & \multirow{5}{*}{$\begin{array}{l}\text { Stable forestland } \\
\text { Changed to } \\
\text { grassland }\end{array}$} & F-F-F & 33942.37 \\
\hline & & F-F-G & 529.18 \\
\hline & & F-G-G & 11.71 \\
\hline & & G-F-G & 1.12 \\
\hline & & W-F-G & 0.16 \\
\hline & \multirow{4}{*}{$\begin{array}{l}\text { Changed to } \\
\text { forestland }\end{array}$} & G-F-F & 7.37 \\
\hline & & W-F-F & 0.72 \\
\hline & & U-U-F & 2.13 \\
\hline & & U-F-F & 0.41 \\
\hline & $\begin{array}{l}\text { Changed to } \\
\text { water area }\end{array}$ & F-W-W & 0.92 \\
\hline & Subtotal & & 553.72 \\
\hline \multirow[t]{15}{*}{$\begin{array}{l}\text { Human-induced } \\
\text { change }\end{array}$} & \multirow{4}{*}{$\begin{array}{l}\text { Changed to } \\
\text { cropland }\end{array}$} & F-C-C & 72.28 \\
\hline & & F-F-C & 674.9 \\
\hline & & C-F-C & 1.5 \\
\hline & & G-F-C & 1.36 \\
\hline & \multirow[t]{4}{*}{$\begin{array}{l}\text { Changed to } \\
\text { forestland }\end{array}$} & C-F-F & 21.09 \\
\hline & & C-C-F & 4.43 \\
\hline & & B-F-F & 0.1 \\
\hline & & B-F-F & 0.1 \\
\hline & $\begin{array}{l}\text { Changed to } \\
\text { grassland }\end{array}$ & C-F-G & 1.14 \\
\hline & \multirow[t]{4}{*}{$\begin{array}{l}\text { Changed to } \\
\text { built-up land }\end{array}$} & F-F-B & 49.09 \\
\hline & & F-B-B & 0.78 \\
\hline & & F-C-B & 0.34 \\
\hline & & C-F-B & 0.08 \\
\hline & $\begin{array}{l}\text { Changed to } \\
\text { unused land }\end{array}$ & F-U-U & 6.56 \\
\hline & Subtotal & F-F-U & $\begin{array}{l}105.24 \\
938.99\end{array}$ \\
\hline
\end{tabular}

Table 2. Forest change trajectories and area statistics $\left(\mathrm{km}^{2}\right)$
During the 20-year study period, the unchanged area of forest took up $78.8 \%$ of the total area. Human-induced changes in forest occupied $2.2 \%$, while natural change area $1.3 \%$. The rest of the total area was occupied by the changes between other land use types. For the natural change area, the trajectory of FF-G obviously dominated, constituting 95.6\%. Cropland converted from forest occupied $79.6 \%$ of total area of the human-induced change trajectories. Due to clear-cutting and selective logging, $111.8 \mathrm{~km}^{2}$ forest was changed to unused land, taking up $11.9 \%$ of total human-induced changed area. About $5.3 \%$ of total human-induced changed area was lost to built-up land. Overall, the total area of human-induced change is 1.7 times than that of natural change in the study area during past 20 years.

\section{DISCUSSION AND CONCLUSION}

Increases of population and intensive agriculture generally have been regarded as main causes of land use and land cover changes (Verburg et al. 1999). Some studies offer statistical evidence supporting the claim that population growth drives or strongly contributes to forest clearance (Allen and Barnes 1985). During past two decades, the total population of the study area increased by $12 \%$ from 1.95 million to 2.18 million. The increased population and consequent demand for grain have caused the increased reclamation of farmland in the study areas in parallel to the loss of forestland. Rapid economic development was partly responsible for land use changes in this study area. Gross domestic product (GDP) of the Yanbian prefecture increased dramatically, indicating a boost in economy and accelerated infrastructure construction. The steady population growth and economic boost coincided with a continuous increase in its developed land area.

During the early years of the People's Republic of China, in order to meet the exigent demands of economic construction and social development, the primary goal of forestry in Northeast China was that of timber production (Yu et al. 2011). Excessive harvesting of timber was encouraged for a long period (Zhou 2006). More than 20 state-owned forestry enterprises were established on the Changbai Mountains. Since 1978 , forestry was to be guided by universal forest protection, extensive reforestation and afforestation efforts, a combination of cutting and planting, and sustainable utilization. However, in conjunction with national economic reforms and the broadening of international relations, excessive logging and neglected cultivation of forests which together nearly exhausted exploitable forest reserves in the region (Zhang et al 2000). The 'food first' agricultural policy exerted the longest influence since the People's Republic of China founded in 1949(Gao et al. 2006). Large area of natural forest in Northeast China was cleared for farming in the past decades. There was a continuous decrease in cropland area between 1986 and 2001, which could be related to the abandonment of low quality croplands on steep terrace and rapid expansion of construction land. Since 2002, cropland area saw an upward trend partially driven by the policy of dynamic equilibrium of the total cultivated land.

The policies of "Grain for Green" (reversing cultivated land to forestland and grassland), the "Natural Forest Conversion Program" (NFCP) and "Construction of an Ecological Province" projects were formally launched in the nation since 1998. Timber harvesting levels in Northeast China have decreased, but forest area and stocking levels have slowly 
increased (Wang et al. 2004). To stimulate motivation for forest protection efforts, the central government has started to pay ecological subsidies to the local foresters whose forests were classified as ecological welfare forests under complete protection since 2003 (Dai et al. 2009). Some forested area was rehabilitated in Yanbian prefecture. Nevertheless, the afforestation area decreased from $48.9 \times 10^{3}$ ha to $6.7 \times 10^{3}$ ha for the period of 1999-2006. The cultivated land in state-owned forestry enterprises is mostly used for growing economic crops such as ginseng and orchards (Zhao et al.2011). The continuous shrinkage and fragmentation of forests requires more effective efforts towards forest protection in the study area.

In short, the area of forestland decreased $4 \%$ in the past 20 years. The quality of forest has severely worsened, and considerable decrease in forest was mainly attributed to reduction of closed forest. The patch numbers of forests increased while the average area decreased. Fractal dimension analysis showed that forest patch shape tended to be regular and simpler indicating more human influence. Forests experienced the process of substantial clearing and fragmentation. The representative temporal trajectories of forest change were driven by human activities including cultivation, logging, reforestation and urban construction. The transformation from forests to croplands is a result of pressure to supply more food and more economic income for the rapidly increasing population and to meet economic demand. The study implies that increased human pressures and socioeconomic development play an important role in the shrinkage and degradation of forests in the past 20 years.

\section{REFERENCES}

Allen J.C., Barnes D.F., 1985. The causes of deforestation in developing countries. Annals of the Association of American Geographers, 75, pp.163-184.

Armsworth P.R., Kendall B.E., Davis F.W., 2004.An introduction to biodiversity concepts for environmental economists. Resource Energ Econ, 26, pp. 115-136.

Baldi G., Guerschman J.P., et al, 2006. Characterizing fragmentation in temperate South America grasslands. Agr Ecosyst Environ,116, pp.197-208.

Cakir G., Sivrikaya F., Keles S.,2008. Forest cover change and fragmentation using Landsat data in Macka State Forest Enterprise in Turkey. Environ Monit Assess, 137, pp.51-66.

Chang Y., Li Y.H., Hu Y.M., Xu C.G., 2003. The preliminary reconstruct of historical forest landscapes in Changbai Mountain Natural Reserve. Quaternary Sciences, 23(3), pp.310 $-317$.

Chang Y., Bu R.C., Hu Y.M., Xu C.G., Wang Q.L., 2004. Dynamics of forest landscape boundary at Changbai Mountain. Chinese Journal of Applied Ecology, 15 (1), pp.15 - 20.

Dai L.M., Zhao F.Q., Shao G.F., Zhou L., Tang L.N.,2009. China's classification-based forest management: Procedures, problems, and prospects. Environ Manage, 43, pp.1162 - 1173.

Dai L.M., Qi L.,Wang Q.W. ,Su D.K. ,Yu D.P., Wang Y. , Ye Y.J. , Jiang S.W., Zhao W.,2011.Changes in forest structure and composition on Changbai Mountain in Northeast China. Ann For Sci, 68, pp.889 - 897.

Deng X.Z., Jiang Q.O., Su H.B., Wu F., 2010. Trace forest conversions in Northeast China with a 1-km area percentage data model. J Appl Remote Sens, 4:041893. doi: $10.1117 / 1.3491193$

Ehman J.L., Fan W. et al, 2002. An integrated GIS and modeling approach for assessing the transient response of forests of the southern Great Lakes region to doubled $\mathrm{CO}_{2}$ climate. Forest Ecol Manag, 155, pp.237 - 255.

Gao J., Liu Y.S., Chen Y.F., 2006. Land cover changes during agrarian restructuring in Northeast China. Appl Geogr, 26, pp.312 - 322.

Hao Z.Q., Yu D.Y., Lin F., Xiong Z.P., Ye J., 2004. Forest resources variation along with the main rivers in typical forest region of Changbai Mountain. Journal of Forestry Research 15(2), pp. 101 - 106.

Harris L. D.,1984. The fragmented forest. University of Chicago Press. Chicago.

Huang F., Wang P., Zhang J.J., 2012.Grasslands changes in the Northern Songnen Plain, China during 1954-2000, Environ Monit Assess, 184(4),pp.2161-2175

Huang W., Jiang Q.O., 2010. Change of forest cover in Northeast China, International Journal of Land Systems, 1(1),pp.23 - 33.

Jiang H., Apps M.J., Zhang Y., Peng C., Woodard P., 1999. Modelling the spatial pattern of net primary productivity in Chinese forests. Ecol Model, 122, pp.275 - 288.

Li M.S., Huang C.Q., Zhu Z.L., Shi H., Lu H., Peng S.K., 2009. Assessing rates of forest change and fragmentation in Alabama, USA, using the vegetation change tracker model. Forest Ecol Manag , 257,pp.1480 - 1488.

Liu H., Zhou Q., 2004. Accuracy analysis of remote sensing change detection by rulebased rationality evaluation with postclassification comparison. Int J Remote Sens, 25, pp.1037 1050 .

Liu J.Y., Liu M.L., Tian H.Q., Zhuang D.F., Zhang Z.X., Zhang W., Tang X.M., Deng X.Z., 2005b. Spatial and temporal patterns of China's cropland during 1990-2000: an analysis based on Landsat TM data. Remote Sens Environ, 98, pp.442 456.

Liu Q.J., Li X.R., Ma Z.Q., Takeuchi N.,2005a.Monitoring forest dynamics using satellite imagery-a case study in the natural reserve of Changbai Mountain in China. Forest Ecol Manag, 210,pp.25 - 37.

McGarigal K., Marks B.J., 1995. FRAGSTATS: spatial pattern analysis program for quantifying landscape structure. US Forest Service General Technical Report PNW 351.

Mertens B., Lambin E.F., 2000. Land-cover-change trajectories in southern Cameroon. Annals of the Association of American Geographers, 90, pp.467 - 494.

Petit C.C., Scudder T., Lambin E.F., 2001. Quantifying processes of land-cover change by remote sensing: resettlement 
and rapid land-cover changes in south-eastern Zambia. Int $J$ Remote Sens, 22, pp.3435 - 3456.

Pichancourt J.B., Burel F., Auger P. ,2006. Assessing the effect of habitat fragmentation on population dynamics: An implicit modelling approach. Ecol Model, 192, pp.543 - 556.

State Bureau of Quality and Technical Supervision of China, 2007. GB/T21010-2007 Classification system of land use status. China Standard Press, Beijing.

Tang L.N., Shao G.F., Piao Z.J., Dai L.M., Jenkins M.A., Wang S.X., Wu G., Wu J.G., Zhao J.Z., 2010. Forest degradation deepens around and within protected areas in East Asia. Biol Conserv, 143, pp.1295 - 1298.

Tang L.N., Li A.X., Shao G.F., 2011. Landscape-level Forest Ecosystem Conservation on Changbai Mountain, China and North Korea (DPRK). Mt Res Dev, 31(2), pp.169 - 175.

Verburg P.H.,Veldkamp T., Bouma J. et al .,1999. Land-use change under conditions of high population pressure: the case of Java. Global Environ Chang, 9, pp.303 - 312.

Wang M.C., Niu X.F.,Yang Y.H., Xing L.X., 2009. Simulation and predicted research on Changbai Mountain landscape pattern process. Journal of Jilin University (Earth Science Edition), 39 (5), pp. 947 - 952

Wang S., van Kooten G.G., Bill W., 2004. Mosaic of reform: forest policy in post-1978 China. Forest Policy Econ, 6, pp.7183.

Wang X.L., Bao Y.H., 1999. Study on the methods of land use dynamic change research. Progress in Geography, 18, pp.81 87.

Wang Z., Zhang B., et al, 2008. Extracting land use information based on topographic map and knowledge rules. Geoinformation Science, 10 (1), pp. 67 - 73.

Wang Z.M., Song K.S. et al, 2009. Shrinkage and fragmentation of grasslands in the West Songnen Plain, China. Agr Ecosyst Environ, 129, pp.315 - 324.

Xiao J., Shen Y., Ge J. et al,2006. Evaluating urban expansion and land use change in Shijiazhuang, China, by using GIS and remote sensing. Landscape Urban Plan, 75, pp. 69 - 80.

Xiao X.M., Boles S., Liu J.Y., Zhuang D.F., Liu M.L., 2002.Characterization of forest types in Northeastern China, using multi-temporal SPOT-4 VEGETATION sensor data, Remote Sens Environ ,82(2-3),pp.335-348.

Yu D.P., Zhou L., Zhou W.M., Ding H., Wang Q.W., Wang Y., Wu X.Q., Dai L.M., 2011.Forest Management in Northeast China:History, Problems, and Challenges. Environ Manage.doi:10.1007/s00267-011-9633-4

Yu D.Y., Hao Z.Q., Jiang P., Xiong Z.P., Yang H., 2004.Landscape pattern variation of forest resources in typical forest zone of Changbai Mountains. Chinese Journal of Applied Ecology, 15(10),pp.1809 -1814.

Zhang P.C., Shao G.F., Zhao G., Le Master D.C., Parker G.R., Dunning J.B. Jr, Li Q.L.,2000. China's forest policy for the 21st century. Science 288(5474), pp.2135 -2136.
Zhang P.C., Zhou X.F., Wang F.Y.,1999. Conspectus of the natural forest protects. China Forestry Press, Beijing, pp. 8-12.

Zhao G., Shao G.F., Hao Z.Q.,Wu W.C., 2001. Remote sensing of forest landscape fragmentation on Changbai Mountain, Acta Ecologica Sinica, 21(9),pp.1393-1402.

Zhao G., Shao G.F., 2002. Logging restrictions in China: a turning point for forest sustainability. J Forest, 100, pp.34 -37.

Zhao J., Wang D., Xu D., 2011. Tourism-induced deforestation outside Changbai Mountain Biosphere Reserve, northeast China. Ann For Sci, 68, pp. 935-941.

Zheng D., Wallin D.O., Hao Z., 1997. Rates and patterns of landscape change between 1972 and 1988 in the Changbai Mountain area of China and North Korea. Landscape Ecol.12 (4), pp.241 -254.

Zhou S.X. ,2006. Forestry in China: historical transitions and industry developments. Thomson, Singapore

Zhou Q., Li B., Kurban A., 2008. Trajectory analysis of land cover change in arid environment of China. Int J Remote Sens, 29 (4), pp.1093 -1107.

\section{Acknowledgements}

The authors would acknowledge the National Grand Fundamental Research 973 Program of China (No. 2009CB426305), National Natural Science Foundation of China for Young Scholars (No.41101434). We thank the reviewers and editors for their comments. 